\title{
Intertextuality in Text-based Discussions
}

\author{
Hamidah Mohd Ismail and Faizah Abd Majid \\ (Universiti Teknologi MARA, Shah Alam, Malaysia) \\ doi:10.7575/aiac.alls.v.2n.1p.18
}

\begin{abstract}
One of the main issues often discussed among academics is how to encourage active participation by students during classroom discussions. This applies particularly to students at the tertiary level who are expected to possess creative and critical thinking skills. Hence, this paper reports on a study that examined how these skills were demonstrated by a group of university students who employed intertextual links during a follow-up reading activity involving small-group text discussions. Thirty undergraduates who were in their fifth semester of a TESL degree programme were prescribed reading texts consisting of two chapters taken from a book. Findings reveal that intertextual links made during text discussions successfully created a "collaborative environment" where beliefs and values were shared judicially among participants. Pedagogical implications for ESL classroom practice include heightening the awareness amongst academics and students of the role of intertextuality in order to promote students' use of their critical and creative thinking skills in a supportive classroom environment.
\end{abstract}

\section{Introduction}

Intertextuality is inherent in reading where a reader creates intertextual links with the text he or she is reading and those that have been read, viewed, or heard. A text is "...constructed of a mosaic of quotations; any text is the absorption and transformation of another" (Kristeva, 1980, p.66). When a reader makes intertextual links, they not only enable the reader to facilitate comprehension of the text, but the links also promote greater use of creative and critical thinking skills (CCTS). Thus it is important that the role of the lecturer includes facilitating students to construct intertextual links during and after reading.

Meaningful reading requires the reader to make connections with the world. In addition, it also involves constructing intertextual readings and interpretations of a text while referring to other texts as well. Hence, for a critical reader, the process of meaning making involves 
reconstructing and revisiting the meanings of a text due to the dialogic nature of the text itself. In a reading classroom, intertextuality can be used as a comprehension strategy where students make text-to-text, text-to-self and text-to-world connections during and after reading.

\section{Intertextuality in text discussions}

The purpose of this study is to examine intertextual connections in an oral discourse where students engage in explicit text discussions in a reading classroom. In a traditional reading class, post-reading activities entail students answering a set of questions pertaining to the prescribed text and followed by a writing exercise based on a related topic. Hence, reading become less meaningful to students and does not encourage the use of CCTS amongst the students in the classroom.

This is further explained by Chi (2001) who affirms that many ESL teachers “... view the text as a collection of words or grammatical and syntactical constructions; students in turn positions themselves to learn only those constructions" (p.248). As a result, students view the reading text as just a "tool for learning that language" (p.248) and missing the opportunity to use their CCTS skills to relate the text totheir experiences, values and viewpoints in their text discussions.

It is important that the lecturer facilitates text discussions while encouraging active participation among students in the classroom. Hence, to promote active and engaging discussions amongst students, Wade and Moje (2000) suggest using the participatory approach where it allows students to interact with the text and other readers. The participatory approach has been regarded as the predominant approach to teaching reading and subject area knowledge (Alvermann \& Moore, 1991; Goodlad, 1994). It is described as "students working in collaborative groups, searching through trade books or on the Internet for answers to their research questions, or discussing a self-selected book in a peer-led book club" (p.609).

Participatory approach is both teacher and student centered. It is teacher centered when the teacher is active and in control while engaged in activities such as lecturing, explaining, asking questions, demonstrating, giving assignments or instructions, monitoring behavior, providing feedback, and assessing students' learning. Meanwhile, student-centered requires participation from the students such as listening, responding, reading aloud or silently, working alone on independent seatwork, and taking tests. 
Intertextuality can easily be applied in participatory approach when the reading text is considered as a tool for both learning as well as constructing new knowledge. In this study, participatory approach was used in an oral discourse constructed in discussions and conversations. Two research objectives were identified in the study.

The first objective was to identify the prominent sources for intertextuality that students frequently used during the text discussions. Chi's (2001) themes of intertextual talk, namely, re-contextualisation, re-storying and reflection, were used as a framework for this study. Recontextualisation occurs when the reader uses schematic knowledge to facilitate understanding of the text. Re-storying transpires when the reader interprets the text by narrating, using his or her personal life and social contexts, as sources. Meanwhile, reflection is a form of reflective thinking where the reader is able to generate his or her own views, values and conclusion. The second objective then was to characterize the three themes by looking at how they emerge during text discussions.

\section{Methodology}

\section{Participants and texts for discussion}

The study employed purposeful selection of participants who were proficient in the English language since the study examined the construction of intertextual links made during text discussions. This key decision is strongly advocated by Creswell (1988) who suggests purposeful selection of participants in a qualitative study. Hence, participants in this study

comprised of third year TESL undergraduate students from Universiti Teknologi MARA who were competent in English, judging from the level of their study as well as their engaging manner and active participation in discussions held in the classroom. Two texts that shared a similar theme were selected for discussion purposes. The texts comprised of two chapters from Pausch's The Last Lecture (2008). The first chapter described how a college professor dealt with grief and his plans for the short future, while the second text represented his strength and positive outlook on living life to the fullest. The two chapters were selected based on their content and relevance to the topic that was discussed in previous lessons.

\section{Data collection and analysis procedures}

Data presented in this study were derived from a classroom of semester five TESL undergraduates with a total of 30 students, comprising of 25 female and 5 male students. The 
students worked in small groups (3 to 4 in a group) and the duration of the study was 3 weeks. In the first week, the first chapter was given to the students and after reading the text, a small-group text discussion ensued, using English as the medium of discussion. Similarly, the second week focused on reading the second text and followed by another round of text discussion. In the third week, discussions were held based on the general concept to create a common knowledge and share similar experiences. Discussions were led by the instructor during the discussions so that more input could be extracted from the participants. Clips of cartoon characters, Tigger and Eeyore, were shown on the projector to ensure that students could identify the characters and link the information to the second text. In each text discussion, students were required to express their opinions to three open ended questions pertaining to the text.

Data were collected during the three lessons where discussions were audio-recorded and transcribed verbatim. The study uses an ethnographic approach to discourse analysis where the true nature of interaction and action were reflected in students' speech and action, and the discourse is analysed from an insider's perspective (Gee \& Green, 1998). Data analyses were

performed using an inductive approach in which the focus was more on patterns and key themes found in the data. Subsequently, the key themes were then interpreted and connected to Chi's (2001) categorisation of intertextual connections.

\section{Results}

The framework of the study was based on Chi's (2001) categorisation of intertextual talk namely, re-contextualisation, re-storying and reflection. Findings demonstrate how intertextual connections emerged in the discourse between the students and how those links promoted the use of CCTS throughout the discussions.

\section{Re-contextualisation}

Re-contextualisation occurred in the discussions when students related their personal experiences and knowledge of the world with the reading text. However, diverse linguistic and cultural background seemed to affect students' interpretation of the texts and as a result, they became more critical and reflective readers. This concurs with Wallace's (1992) opinion that linguistic background plays a major role in a text discussion where it allows students to re-contextualise the text by re-defining and affirming their stance of what could be thought as appropriate to the immediate context. The findings revealed that text discussions allowed the 
exchange of differing viewpoints and helped the students become more critical and reflective readers. The following example illustrates this situation.

\section{Example A: Discussion data extracted from Group \#4}

S3: I think Randy loved his work too much. All he could be thinking was work; he should be thinking about spending time with his family.

S1: Agreed. He was going to die. So spend time with his wife and kids. If I were him, I'd quit my job and spend my remaining days with my loved ones. How could he be so selfish and think only about his work and his ambitions?

S4: No. You're wrong. He's not selfish. If you notice, his lecture revolved around his family. I think this is his way of telling everyone how much he loved his family. The way he talked about his wife and kids ... very touching ... full of love and affection. He didn't care much about his short life ... more concerned about how his wife and kids would cope without him.

S2: Think you're right. The lecture's for his family, right?

S4: Of course. It's more for the future.

L: So, do you think he's being selfish here?

S1: Initially I thought he was selfish because he wanted to do the lecture and spend precious little time preparing work. Now I understand that it was for his wife and kids ... telling the world how much he loved them.

L: How did his family feel about this?

S3: The way I interpret it, I think they must have felt left out because he was spending too much time preparing the lecture. He didn't even plan for his wife's birthday! For it to be the last birthday he could celebrate with her, I would have felt hurt if I were the wife.

S2: Most of the people I know who were dying spent much of their time on the hospital bed surrounded by tearful relatives and friends. I want to be like Randy instead. All the tears in the world will not change the fact that death is already knocking on your door.

As shown in Example A, students' interpretation led to some interesting exchange of viewpoints. Student 1 (S1) initially perceived the author as being a workaholic and selfish man. But as the conversation progressed and upon hearing others' opinions, S1 modified his thoughts as they helped each other share what was read and understood. Hence, recontextualisation provided students with the opportunities to re-look at the textual meaning and collaboratively re-examine their comprehension and textual interpretation of the multiple texts.

Re-storying

During the process of re-storying, students reconstructed themselves by forming narrative interpretations using intertextual links between language, knowledge and experience. In the study, students spontaneously shared their personal experiences during text discussions as they shared their own life experiences in their conversations, thus making the discussions longer and more engaging to all.

\section{Example B: Discussion data extracted from Group \#2}

S3: Randi was cool ... he didn't even cry. Why did he hide his emotions? 
S1: Not cool for a man to cry. In movies, the women would cry for days till their eyes get swollen as they sought pity from the others. That's what they wanted to hear from others ... sympathy. But guys are portrayed as the tough ones ... like in Indian movies, they would still be walking even when shot many times.

S2: I would be in tears for days, if I were him.

L: Do we know anybody who has cancer and still fighting?

S4: My close friend had cancer. She was very calm, like Randy. She never gave up hope, tried all types of treatments hoping that the cancer will go away. But like Randy, she got her loved ones to support her. We were all sad but had to hide it from her because we're afraid that she'd lose her faith. I can understand how Randy felt. My friend died recently. But I am still awed by her courage and determination.

S3: Kylie Minogue has cancer too right? Breast cancer, I think. But she's doing okay after chemo. Just look at her today. She looks healthier than any of us and the positive vibes that radiates from her. She's among a lot of other people with cancer and they survived. I strongly feel that must've been something to do with will-power and fate too, of course.

S2: You're right. At the end of the day, it's all God's will. As a Muslim, we can never give up hope as God determines our fate. Besides prayers, we must not stop trying to look for a cure.

S1: My aunt was strong. She fought hard and never stopped, never gave up hope. But in the end she lost the battle. It was a long battle for her and her family too. She had breast cancer but discovered it at late stage. Her kids were so affected after her death that they stayed away from school and friends. I feel so sorry for them but just don't know how to help them cope with the loss.

During the discussions, students' personal life and social contexts become two major contributors in the re-storying process as they shift from the writer's to their own interpretation of the text. In the example, student 1 (S1) shared her personal experience and concerns about a close relative who had to cope with a similar situation. By sharing individual voices in the discussion, they shifted their attention away from the text and focused on personal life resources and social contexts. Hence, similar to Chi's (2001) findings, students used re-storying as an intertextual link to interconnect the past, current and future literary experience by using the text as well as themselves as resources for learning. This proved to be a very meaningful learning experience for the students as they both explored and expanded in a social act that allowed them to step out from the "inside $m e$ " to the "outside $u s$ " (Chi, 2001, p. 252).

\section{Reflection}

The process of reflection originates from John Dewey's (1933) reflective thinking in which there is the basic assumption that learning is attributed to the process of reflection. Hence, reflection in text discussion requires questioning strategy to promote it. In the study, students were made aware of the context of situation and the role of the instructor was to initiate the discussion with a real situation - why people avoid talking about death.

\section{Example C: Discussion data extracted from Group \#1}

L: Why do people stay away from talking about death? 
S4: It's sadness, grief. People don't like to be reminded that they are going to die one day, what more if you're told that you are incurable and death is the only option.

S1: Reminds me of my dad. I don't like talking about it ... makes me sad and lonely.

S2: Sorry to hear about your dad, but as a good Muslim you must include your dad in prayers. That's how a good son should do. Perhaps, God will answer your prayers and place him in heaven.

S3: I think people don't talk about death because they are scared of dying. Death is like a full stop. There's no going forward ... just a stop. But, am amazed at how Randy managed to put aside all those fears and just continued life as if he wasn't dying. Not everyone has those guts, you know. I wish I could be as strong as he was.

L: Why do you think Randy did that?

S1: So that his wife and kids wouldn't feel sad. I think he wanted to enjoy life as long as he could. You know, there's only so much time left, so why waste it?

S4: Though we are only human, but we can still manage our life to the fullest. Like Randy, I think the best way is to look back once in a while to see what else you need to accomplish in life so that you can manage the present and plan for the future. Randy did that, he knew what he wanted in life and he worked hard to accomplish them. And he managed to complete writing the lecture and delivered it even though he had to deal with his sickness. That is truly an icon to me ... I admire his strength and willpower.

S2: Yeah, and he created a legacy by writing that book. It's a best seller and he got the world to know how much he loved his family and life.

Intertextual connection was evident when students reflected on their prior knowledge and life experiences in a meaningful context. Reflection, as an intertextual link, allowed students to use their CCTS during thinking, talking and reflecting processes. When students became engaged in the text discussion, their reflective thoughts guided their talk and the issues were then connected to the text being read. As such, the story read from the text became secondary to the process. In example C, student 4 (S4) re-examined his earlier thoughts about dealing with death and began to see the context from a broader perspective. As his viewpoint changed positively, he was able to comprehend the textual meanings reflectively.

\section{Conclusion}

The idea behind this study is to offer fresh insights on how to promote intertextual connections in reading classrooms using the participatory approach in a text-based discussion. Both teacher and student-centered approaches were utilized during the text discussions and the findings revealed that students were able to construct intertextual links using their critical and creative thinking skills in a very meaningful context. Intertextual links constructed during discussions allowed the students to share their personal experiences about social issues, relationships, and life in general; hence giving the students a broader perspective beyond the texts themselves.

Intertextuality is a potentially rich classroom resource in promoting reading comprehension and textual interpretation. By highlighting the intertextual links students make during text discussions, they become more engaged learners and heighten their awareness of their own 
learning process. However, the role of the lecturer is also important in ensuring that all students participate actively in the discussions as well as provide a supportive and collaborative classroom environment for the students.

Some implications of this study involve both areas of research and teaching. Due to the qualitative nature of this study, a more comprehensive research involving a larger number of participants and different levels of language proficiency is needed for an in-depth investigation of how intertextual links can promote greater comprehension and textual interpretation in text-based classroom discussions. More effort should also be forwarded to explicitly raise both teachers and students awareness of the importance of constructing intertextual links to permeate their text discussions. This is particularly important in ESL classroom settings where students require more classroom opportunities to share and exchange ideas based on their personal and literary experiences. With intertextual links, there exists multiple interpretive possibilities and both students as well as the teacher will have a broader perspective that goes far beyond the text itself.

\section{References}

Alvermann, D.E., \& Moore, D.W. (1991). Secondary school reading. In R. Barr, M.L. Kamil, P.B. Mosenthal, \& P.D. Pearson (Eds.), Handbook of reading research: Volume II (pp. 951-983). White Plains, NY: Longman.

Chi, F.M. (2001). Intertextual talk as collaborative shared inquiry in learning English as a foreign language. Proceedings of the National Science Council, ROC Part C: Humanities and Social Sciences, 11(3), 247-255.

Creswell, J. W. (1988). Qualitative inquiry and research design: Choosing among five traditions. Thousand Oaks, CA: Sage Publications.

Dewey, J. (1933). How we think: A restatement of the relation of reflective thinking to the educative process. Boston: Houghton Mifflin Company.

Gee, J. P. \& Green, J. L. (1998). Discourse analysis, learning, and social practice: A methodological study. Review of Research in Education, 23, 119-169.

Goodlad, J.I. (1994). What schools are for. Bloomington, IN: Phi Delta Kappa Educational Foundation Collie, J., \& Slater, S. (1987). Literature in the language classroom: A resource book of ideas and activities. Cambridge, UK: Cambridge UP.

Kristeva, J. (1980). Word, dialogue, and novel. In L. S. Roudiez (Trans.), T. Gora et al. (Eds.), Desire and Language (pp. 64-91), New York: Columbia University Press

Pausch, R. (2008). The last lecture. New York, NY: Hyperion.

Wade, S.E., \& Moje, E. B. (2000). The role of text in classroom learning. In M.L. Kamil, P.B. Mosenthal, P.D. Pearson, \& R. Barr (Eds.), Handbook of reading research: Volume III (pp. 609-627). Mahwah, NJ: Erlbaum.

Wallace, C. (1992). Reading. Oxford: Oxford University Press. 